\title{
Paleopedological record along the loess-paleosol sequence in
} Oberlaab, Austria

\author{
Elizabeth Solleiro-Rebolledo, Hector Cabadas, Birgit Terhorst
}

How to cite:

Solleiro-Rebolledo, E., Cabadas, H., Terhorst, B. (2013): Paleopedological record along the loess-paleosol sequence in Oberlaab, Austria Paleopedological record along the loess-paleosol sequence in Oberlaab, Austria. - E\&G Quaternary Science Journal, 62 (1): 22-33. DOI: 10.3285/eg.62.1.03

Abstract:

A detailed study of a loess-paleosol sequence in Oberlaab, Upper Austria, is presented with emphasis on macro- and micromorphological features, grain size distribution, rock magnetism properties, and weathering degree that allows correlation with other loess-paleosol sequences in neighboring areas, and interpretation of main pedogenic trends. The studied sequence comprises four paleosol complexes, which likely developed during four interglacial stages MIS 11, 9, 7 and 5e, and a modern soil. The oldest paleosol complex (OL5) represents three phases of soil formation, and distinct sedimentary events never reported in the area, with strong reductomorphic properties. The OL4 profile also results from three phases of pedogenesis with increased reductomorphic features in the deepest zone (affected by cryoturbation events). OL3 has abundant features related to gleyic/stagnic processes, but shows signs of clay illuviation. OL2 (Eemian soil) correlates with the MIS 5e. This paleosol shows higher degrees of clay illuviation and weathering, and fewer features related to reductomorphic processes. The modern soil is also polygenetic and constitutes a pedocomplex. Its lowermost part is formed by Würmian glacial deposits, where no well-developed soils are found; only reworked materials and pedosediments. Main pedogenic trends in the sequence are clearly differentiated. All of the paleosols were formed in humid environments, but differing in drainage conditions. The base, with OL5 and OL4 paleosols, was more affected by gleyic processes, while in the upper paleosols, especially OL2, clay illuviation is dominant. We interpret such differences to be caused by the topographic position. The basal paleosols were more affected by fluvioglacial processes due to their position on top of the terrace. The upper paleosols received increased amounts of sediment through fluvial, colluvial and aeolian (loess) input.

\section{Das paläopedologische Archiv der Löss-Paläoboden-Sequenz in Oberlaab, Österreich}

Kurzfassung:

Eine detaillierte Untersuchung einer Löss-Paläoboden-Sequenz in Oberlaab, Oberösterreich, wird vorgestellt, deren Schwerpunkt auf makro- und mikromorphologischen Merkmalen, der Korngrößenverteilung, magnetischen Gesteinseigenschaften und dem Verwitterungsgrad liegt. Die untersuchten Aspekte ermöglichen einerseits eine Korrelation mit anderen Löss-PaläobodenSequenzen in benachbarten Gebieten und andererseits die Interpretation wichtiger pedogenetischer Entwicklungen. Die untersuchte Sequenz besteht aus vier Paläoboden-Komplexen, deren Entwicklung sehr wahrscheinlich während der vier Interglaziale MIS 11, 9, 7 und 5e stattfand, sowie einem rezenten Boden. Der ältere Paläobodenkomplex (OL5) beinhaltet drei Phasen der Bodenbildung mit unterschiedlichen Sedimentationsereignissen, die in diesem Gebiet bislang noch nicht beschrieben wurden Darüber hinaus finden sich stark redoximorphe Merkmale. Das Profil OL4 zeigt ebenfalls drei Bodenbildungsphasen mit zunehmend redoximorpher Prägung im unteren Bereich, wobei eine Überprägung durch kryoturbate Prozesse sichtbar ist. Auch an OL3 konnten Merkmale grund- bzw. stauwasserbeeinflusster Prozesse dokumentiert werden, es finden sich aber auch Hinweise auf Tonverlagerung. Der Eemboden OL2 entspricht dem MIS 5e. Hier zeigen sich die intensivste Tonverlagerung und der stärkste Verwitterungsgrad, sowie ein Rückgang der redoximorphen Merkmale. Auch der rezente Boden ist polygenetisch und stellt sich als Pedokomplex dar. Der unterste Bereich besteht aus würmzeitlichen glazialen Ablagerungen. In diesem Profilteil finden sich keine gut entwickelten Böden, sondern ausschließlich umgelagertes Material und Pedosedimente.

Die vorherrschenden pedogenetischen Prozesse in der Sequenz können klar abgegrenzt werden. Alle Paläoböden entstanden unter humiden Bedingungen, wobei aber jeweils eine unterschiedliche Drainage vorhanden war. Die Profilbasis, die durch die Paläoböden OL5 und OL4 gebildet wird, ist stärker von Grundwasser beeinflusst, während in den oberen Paläoböden, v.a. in OL2, die Tonverlagerung dominiert. Es ist anzunehmen, dass diese Unterschiede in der topographischen Position begründet sind. Die unteren Paläböden sind aufgrund der tieferen Lage der Terrasse stärker von glazifluvialen Prozessen betroffen, während die oberen Paläoböden nach der Sedimentation von großen Materialmengen (fluvial, kolluvial und/oder Löss) eine höhere Position einnehmen.

Keywords: Middle Pleistocene, loess, paleosol, Oberlaab, pedogenesis

Addresses of authors: E. Solleiro-Rebolledo, Universidad Nacional Autónoma de México, Instituto de Geología. Circuito de la Investigación Científica, 04510, México DF, Mexico. E-Mail: solleiro@geologia.unam.mx; H. Cabadas, Universidad Autónoma del Estado de México, Facultad de Geografía, Cerro de Coatepec s/n, Cd. Universitaria, Toluca, México. E-Mail: hvcabadasb@uaemex.com; B. Terhorst, University of Würzburg, Institute of Geography and Geology, Am Hubland, D-97074 Würzburg/Germany. E-Mail: birgit. terhorst@uni-wuerzburg.de 


\section{Introduction}

Loess/paleosol sequences are a valuable source of information about past climatic and environmental conditions during the Quaternary, and are one of the most complete terrestrial records of glacial-interglacial cycles (PÉcsi 1990; Pécsi \& Schweitzer 1993; Muhs \& Bettis 2003) successfully correlated to the global climate proxies as marine isotope curves (KUKLA 1978; BRONGER et al. 1998). In temperate zones they have provided reliable information about paleoenvironmental change, particularly for the last glacial/interglacial cycle, as in Eurasia (LIU 1985; RozYCKI 1991; Sun et al. 1997; Muhs \& Bettis 2003; Feng et al. 2007), United States (Muns \& BetTis 2000; Bettis et al. 2003), and South America (MuHs \& ZÁrate 2001; QuATtrocchio et al. 2008). In Austria, several works contain detailed descriptions for loess-paleosol sequences (e.g. FINK 1976; KoHL 1976; Haesaerts et al. 1996; Neugebauer-Maresch 1996; Niederhuber 1997; Terhorst 2007). However, our understanding of the pedostratigraphy and pedogenesis of loessic paleosols remains incomplete. In particular, in Upper Austria, where over a century of research on Pleistocene landscape history has been conducted since the classical works of PENCK \& BRÜCKNER (1909), loess-paleosol records are still yielding new data for regional paleoenvironmental reconstructions.

We studied a loess-paleosol sequence in Upper Austria, situated on the top of a Mindel fluvioglacial terrace. The Austrian stratigraphic table classifies the classical Mindel glacial as belonging to the MIS 12 (ÖSTERREICHISCHE Stratigraphische Kommission 2004). VAN Husen (2000) and VAN HuSEn \& ReITNER (2011) correlate Mindel glacial sediments in the Eastern Alpine Foreland with the MIS 12, while the Rissian deposits are associated to the MIS 6. On the basis of pedostratigraphical analyses in the Linz/ Wels area, Terhorst (2007; 2013, this volume) and TerHORST et al. (2011) propose a similar correlation for the loess/paleosol sequence of Oberlaab, which includes four interglacial paleosols located on top of the Mindel terrace. These paleosols are linked to MIS 11, 9, 7 and 5, respectively (TERHORST et al. 2011, 2013), and span parts of the Middle to the Upper Pleistocene. According to Terhorst (2007) and Terhorst et al. (2011, 2013) Middle Pleistocene sequences in Upper Austria are the result of an alternation of geomorphogenetic-pedogenic processes. During Middle Pleistocene times, geomorphodynamics in the region were controlled by unstable glacial periods (causing phases of erosion and sedimentation), which alternated with stable interglacial periods and soil formation. Using the concept of "soil memory" (in the sense of TARgulian \& GorYACHKIN 2004) the resulting paleosols contain information about environmental conditions of the interglacials.

In Oberlaab, we conducted a paleopedological survey, which involved a multidisciplinary approach to identify types of pedogenesis and degrees of paleosol development. Previously, Terhorst (2007) studied a similar sequence in the loam pit of Oberlaab, which comprises thick pedocomplexes, related to four interglacial periods, covering a time span of $>400 \mathrm{ka}$. In this paper, we contribute a detailed morphological description of pedostratigraphic units accompanied by a set of quantitative pedogenetic characteristics: morphometric analysis of diagnostic pedofeatures, grain size distribution, magnetic parameters (magnetic susceptibility and frequency dependence of susceptibility), as well as geochemical indicators of weathering. These characteristics provide a base for reliable comparison between buried paleosols and the Holocene surface soil, in order to establish differences in the typology and grade of development of the main pedogenic processes. The resulting paleopedological record contributes to the reconstruction of the environmental conditions of the four last interglacials and provides complementary data for the regional geomorphological and stratigraphic schemes.

\section{Materials and methods}

The study site is situated in a quarry exploited for clay for brick production, $1.5 \mathrm{~km}$ to the north of Wels, Austria (for details see Terhorst 2013, this volume). The general stratigraphy was presented by TERHORST (2007), who has recognized four interglacial paleosols. The loess/paleosol sequence of Oberlaab was developed on a Mindel terrace (Younger Deckenschotter). The basement of the sequence is formed by gravels, exposed previously in a cut operation during 2003. The whole sequence has a thickness of $15.80 \mathrm{~m}$, which has been sectioned and labeled as the units OL1, OL2, OL3, OL4 and OL5. Each of these sections contains a soil/paleosol/pedocomplex unit (Figure 1).

Genetic horizons of modern soil and paleosols were defined according to their morphology following the World Reference Base (IUSS WorkIng Group WRB 2007). We observed ped features under a $10 \mathrm{X}$ lens in the field. In all cases, interpretation was based on comparison of paleosols with the modern soil.

\subsection{Micromorphology}

For micromorphological studies we took undisturbed samples from every genetic horizon (Figure 1). Thin sections were prepared and described with the guide of Bullock et al. (1985).

To quantify the proportion of pedofeatures in different horizons, selected thin sections were scanned with high resolution (4800 and 9600 dots per inch); the digital image was later analyzed with the Image Pro Plus v.6.0 software. A contrast enhancement of every image was produced to distinguish zones with diffuse contacts to the groundmass, using the blue RGB channel acquisition. The false color was used for the segmentation of areas occupied by each pedofeature with a previous conversion to shades of grey. The most important features analyzed were: 1) iron nodules and impregnations, 2) bleaching areas and 3) clay coatings. However, in most of the thin sections the complex mixture of iron and clay was very difficult to separate by the software algorithms. Thus, we decided to study clay coatings semi-quantitatively using visual schematic petrographic diagrams (CASTRO 1989). Porosity was not estimated in the total average, because in some thin sections voids had the same color as felsic minerals.

Besides micromorphometric analysis of selected pedofeatures we established the assemblage of the primary minerals, their distribution in different size fractions and their weath- 


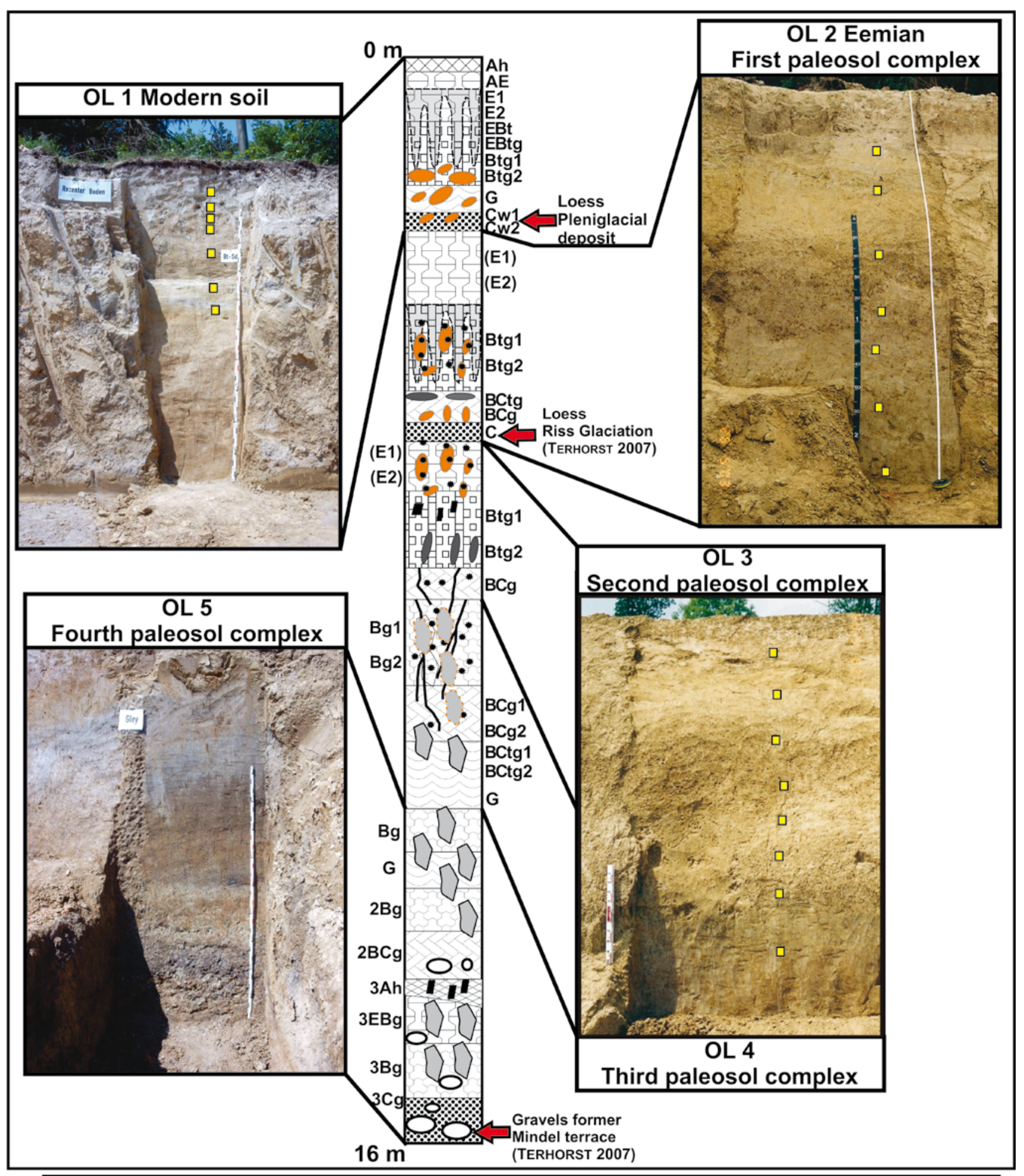

\begin{tabular}{|llll|}
\hline $\begin{array}{l}\text { Gley lenses } \\
\text { Fe mottles }\end{array}$ & Vertical fissures & - Fe-Mn concretions & $\cdots$ - Oxidized zone \\
& $\begin{array}{l}\text { Gley tongues and } \\
\text { mottles }\end{array}$ & I Charcoal & $\begin{array}{l}\text { O Rock fragments } \\
\square \text { Samples for } \\
\text { micromorphology }\end{array}$ \\
\hline
\end{tabular}

Fig. 1: Oberlaab loess/paleosol sequence on top of a Mindel terrace (Young Deckenschoter), which includes four interglacial paleosols and the modern soil. Abb. 1: Stratigraphie der Löss-Paläoboden-Sequenz Oberlaab, sowie ein allgemeiner Überblick über alle vier Paläoböden und den rezenten Boden. 
ering status basing on the crystallooptical properties under magnification with a petrographic microscope.

\subsection{Laboratory analyses}

Size fractions were separated in OL1, OL2, OL4 and OL5. OL3 was not evaluated due to the lack of samples. The sand fraction $(2-0.063 \mathrm{~mm})$ was separated by sieving; silt $(0.063-0.002 \mathrm{~mm})$ and clay $(<0.002 \mathrm{~mm})$ fractions by gravity sedimentation with previous destruction of aggregating agents; $\mathrm{H}_{2} \mathrm{O}_{2}(15 \%)$ was used for organic matter, and dithionite-citrate-bicarbonate (DCB) for iron oxides. As the deposits had no carbonates, no additional pre-treatments were necessary for their destruction.

For magnetic measurements, $200 \mathrm{~g}$ samples were collected at roughly $20 \mathrm{~cm}$ intervals, homogenized, and placed in $8 \mathrm{~cm}^{3}$ acrylic boxes. Magnetic susceptibility $(\chi)$, which is a measure of the concentration of magnetic minerals, was registered in all samples at low $(0.47 \mathrm{kHz})$ and high frequencies $(4.7 \mathrm{kHz})$ with a Bartington MS2B dual sensor. We calculated frequency dependence of susceptibility $\chi \mathrm{fd} \%$ as $[(\chi \mathrm{lf}-\chi \mathrm{hf}) / \chi \mathrm{lf}] 100$, to approximate possible ultrafine $(<0.05 \mu \mathrm{m})$ superparamagnetic (SP) contribution. DeARING (1994) and DeARING et al. (1997) suggest that values of $\mathrm{cfd} \%<2 \%$ point to a content of $<10 \%$ of SP (superparamagnetic) grains; values around $8 \%$ indicate a SP contribution of $75 \%$, and between $10-14 \%$, the material is domain by SP particles.

\subsection{Geochemical indices of weathering}

Bulk chemical composition was obtained by X-ray fluorescence in a Siemens SRS 3000 spectrometer, using powder pellets at the Institute of Geology, UNAM. All results were calculated by weight on oven $\operatorname{dry}\left(105^{\circ} \mathrm{C}\right)$ soil.

As the parent material of the section is mainly loess rich in silica, we decide to evaluate the degree of weathering using the chemical index of alteration (CIA). CIA measures changes in major cation content in relation to immobile alumina, instead of changes in the silica/alumina composition. This proxy was first proposed by NesBItT \& Young (1982) and introduced in loess studies by LIU et al. (1995). CIA is evaluated following the formula: CIA= $\left(\mathrm{Al}^{2} \mathrm{O}^{3} /\left(\mathrm{Na}{ }^{2} \mathrm{O}+\mathrm{CaO}+\mathrm{MgO}+\mathrm{K}^{2} \mathrm{O}\right)\right)^{*} 100$. The reason to use this weathering index is the high concentration of K-feldspar found in the mineralogical assemblage, according to BuGGLE et al. (2011) and the lack of carbonates (thus the $\mathrm{CaO}$ content is only associated to silicates). A value near 100 represents the highest degree of weathering, while values lower than 50 correspond to fresh sediments.

\section{Results}

\subsection{Morphology of the Oberlaab paleosol sequence}

The study sequence in Oberlaab includes a modern soil (OL1) and 4 paleosol units (OL2 to OL5) from the top to the bottom (Figure 1).

OL1. Modern soil (depth 0-190 cm). The OL1 soil shows a well-developed profile with Ah-AE-E1-E2-EBt-EBtgBtg1-Btg2-G-Cw horizons. The Ah horizon is thin (5 cmthick), dark brown, very porous, with a consistent granular structure and a high density of roots. The transitional AE horizon is also thin (10 cm thick) and paler than Ah. The underlying E horizon is $30 \mathrm{~cm}$ thick, divided into E1 and E2. This division was made because E2 is notably darker with less silt. In general, the E horizon is light gray, silty and with subangular blocky structure. The contact with the underlying Btg1 is also transitional, through the EBt and EBtg horizons (45-100 cm). Light gray tongues of compacted, silty material, starting from the E horizon, enter into Btg $(100-150 \mathrm{~cm})$. These tongues are separated from each other by $15 \mathrm{~cm}$ in some cases, and $25 \mathrm{~cm}$ in others. Roots do not penetrate the tongues. The Btg1 horizon is grayishyellowish brown, with yellowish brown mottles. Clay coatings are thick and frequent. The Btg2 horizon has a similar color, but is distinguished by a network of cracks. The cracks boundaries are gray, contrasting with the brownish color of the matrix. The lowermost G horizon $(150-160 \mathrm{~cm})$ is gray in color, more dense and has a silty texture. The subangular blocky peds exhibit a platy structure. The Cw horizon (160-190 cm) corresponds with the uppermost part of a pale-yellow, silty, loess-like deposit, showing horizontal gray bands.

The underlying $\mathrm{Cw}$ horizon corresponds to a loess-like deposit (190-390 cm). This material constitutes a pedosediment, which contains a mixture of sediments and reworked soils.

OL2. Eemian soil (depth 390-670 cm). The next stratigraphic level corresponds to the Eemian soil (Figure 1), and contains a sequence of (E1)-(E2)-Btg1-Btg2-BCtg-BCg$\mathrm{C}$ horizons. Vertical cracks cross the first $200 \mathrm{~cm}(390-590$ $\mathrm{cm}$ ), filled by a gray material, of which the inner part is black. The boundary between the gray and black materials is reddish.

Because of the paler color (brownish yellow) of the first $60 \mathrm{~cm}(390-450 \mathrm{~cm})$, we initially assumed that the material corresponds to an E horizon, which is divided into E1 and E2 with a silty loam texture. However, a more detailed morphological study revealed that the horizon is constituted by two layers of reworked pedosediments. The loesslike sediment is affected by weak pedogenesis, with rounded sediment grains and soil fragments. The soil fragments occur as small subangular blocks breaking into granular aggregates, with a tendency to form a weak platy structure. Moderate amounts of 2-3 mm-diameter Fe/Mn-concretions were detected, varying from dark brown to red. The transitional limit to the underlying Btg horizon (Btg1 and Btg2) is wavy. The Btg horizon $(450-540 \mathrm{~cm})$ is yellowish brown, darker than the reworked pedosediments of the upper part, more compact, and clayey. Btg1 has a better developed platy structure, which breaks to subangular blocks. Clay coatings are abundant. In the upper surface of the platy aggregates, discontinuous dark brown clay coatings are present. In this horizon the vertical cracks are covered by clay and silt coatings (the latter are observable with a 10X-hand lens). Fe/Mn-concretions are abundant. The horizon shows strong mottling, which consist of bright yellow areas with brownish and grayish zones. These spots are mainly oriented along the vertical cracks. In Btg2, clay coatings are fewer and more disperse. The BCtg horizon $(540-570 \mathrm{~cm})$ is paler and also compact. Here, fewer clay coatings and Fe-Mn concretions are detectable. Vertical 

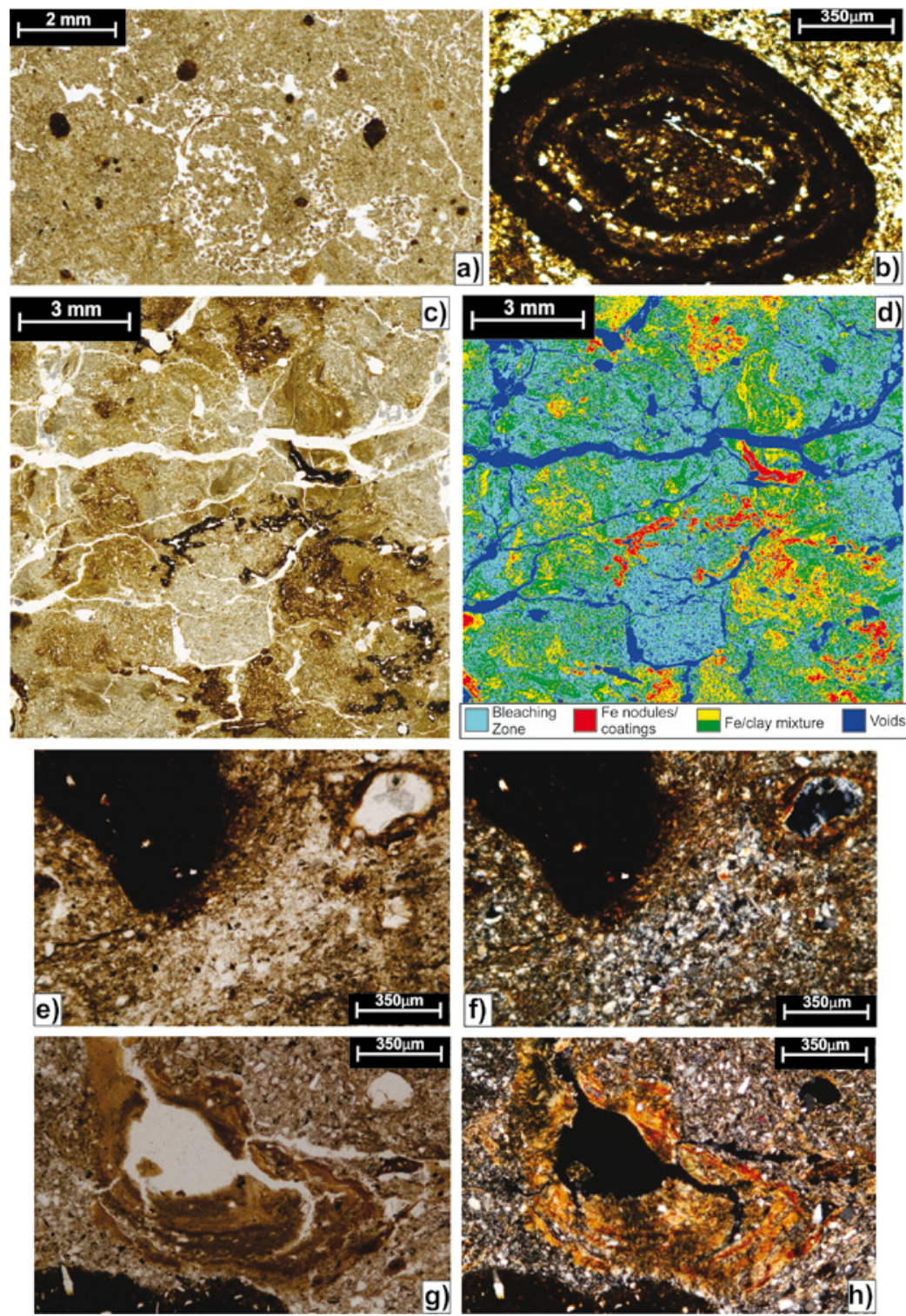

Fig. 2: Micromorphology of the study section a. Coalescent excremental infillings in chambers in $A E$ horizon of the modern soil. High resolution image (4600 dpi) of scanned thin section.

b. Concentric iron nodule in $G$ horizon of the modern soil, photomicrograph, plane polarized light (PPL). c. Bleached zones in the groundmass of $B C \mathrm{~g} 1$ horizon in OL4. High resolution image (4600 dpi) of a scanned thin section.

d. Same as 2c: Image analysis in false color.

e. Bleached zone (center) with sharp contact with the groundmass in OL3-BCg horizon. Fe nodules showing abrupt boundaries with the groundmass, photomicrograph (PPL).

f. Same as $2 e$, cross polarized light (XPL).

g. Clay coatings around a void associated with a bleached zone in OL3-Btg1 horizon. The dark-yellowish color of the clay is related to the presence of iron and coarse silt fraction, photomicrograph (PPL).

h. Same as $g, X P L$. Note the high interference color related to the presence of 2:1 clay structure.

Abb. 2: Mikromorphologie des untersuchten Abschnitts: a. Koagulierte Exkrementfüllungen in Hohlräumen im AE-Horizont des rezenten Bodens. Hochauflösende Darstellung (4600 dpi) von gescanntem Dünnschliff. b. Konzentrische Eisenkonkretion im G-Horizont des rezenten Bodens. Mikroskopaufnahme unter eben polarisiertem Licht (plane polarized light, PPL).

c. Gebleichte Zonierung in der Matrix des BCg1-Horizonts von OL4. Hochauflösende Darstellung (4600 dpi) von gescanntem Dünnschliff.

d. Wie 2c: Falschfarbenbildanalyse.

e. Gebleichter Bereich (Zentrum) in scharfer Abgrenzung zur Matrix im BCg-Horizont von OL3. Mikroskopaufnahme (PPL). f. Wie 2e., gekreuzte Polarisatoren (cross polarized light, XPL).

g. Kugelförmige Struktur (roter Rahmen rechts) in OL4. Hochauflösende Darstellung (4600 dpi) von gescanntem Dünschliff.

h. Tonüberzüge in einem Hohlraum in Verbindung mit einer Bleichzone in Btg1 in OL3. Die dunkelgelbe Farbe des Tons ist bedingt durch den Eisengehalt und der Korngrößenfraktion Grobschluff. Mikroskopaufnahme (PPL). oriented channels are also present. They are filled by laminated clay (dark brown) and silt coatings (yellow and gray). The BCg horizon $(570-635 \mathrm{~cm})$ is similar, but here coatings are very rare. The most conspicuous feature is the change of color as well as the intensity of gleyic characteristics throughout the horizon. Grey, horizontally oriented lenses appear in the first $15 \mathrm{~cm}$. The matrix of the next $30 \mathrm{~cm}$ is grayish-yellowish brown with some yellow spots. The lower part is light yellowish brown and has diffuse mottles. The C horizon $(635-670 \mathrm{~cm})$ has a silty loam texture and a brown to yellowish brown color with rusty mottles. There are no Fe concretions. Structure is weak varying from subangular blocky to massive.

OL3. Second paleosol complex (depth 670-900 cm). Similar to the Eemian soil in OL2 (Figure 1) this unit has two levels of reworked pedosediments (E1 and E2) on the top $(670-730 \mathrm{~cm})$, which are superimposed on the following compact horizons:Btg1-Btg2-BCg. The first pedosediment level (30 cm thick) is strongly mottled. Matrix has a light brownish yellow color with gray stagnic mottles and round rusty patches ( 1 to $1.4 \mathrm{~cm}$ in diameter). Structure shows large subangular blocks and inside the block aggregates there is a tendency to form a thin platy structure. Vertical cracks are frequent and filled by clay pellets. There are bleached areas with light colors that contrast with with darker stagnic zones. The second level of reworked pedosediments ( $30 \mathrm{~cm}$ thick) corresponds to a strongly patchy silty loam. In this case the color is paler because of dominant grayish mottles. Rounded mottles are covered by dark brown clay coatings. Btg1 $(730-790 \mathrm{~cm})$ is characterized by a dark brown matrix with even darker mottles that alternate with brownish gray spots. Structure is very well developed in strong angular blocks, which break into smaller angular aggregates. Dark brown Fe/Mn-concretions with a size from 1 to $5 \mathrm{~mm}$ diameter are frequent. Dark brown clay coatings are present; however, they are very rare and appear in few peds. Small quantities of charcoal are present and associated to thin root channels. Due to an increase of vertically oriented gley mottles, Btg2 $(790-860 \mathrm{~cm})$ has a clear change in color as well as in structure (subangular blocks). In this horizon we detect a decrease in the abundance of clay coatings, and in the quantity and size of the Fe-concretions. Some rounded rock fragments are found. The $\mathrm{BCg}$ horizon $(860-900 \mathrm{~cm})$ is strongly patchy. Matrix is 


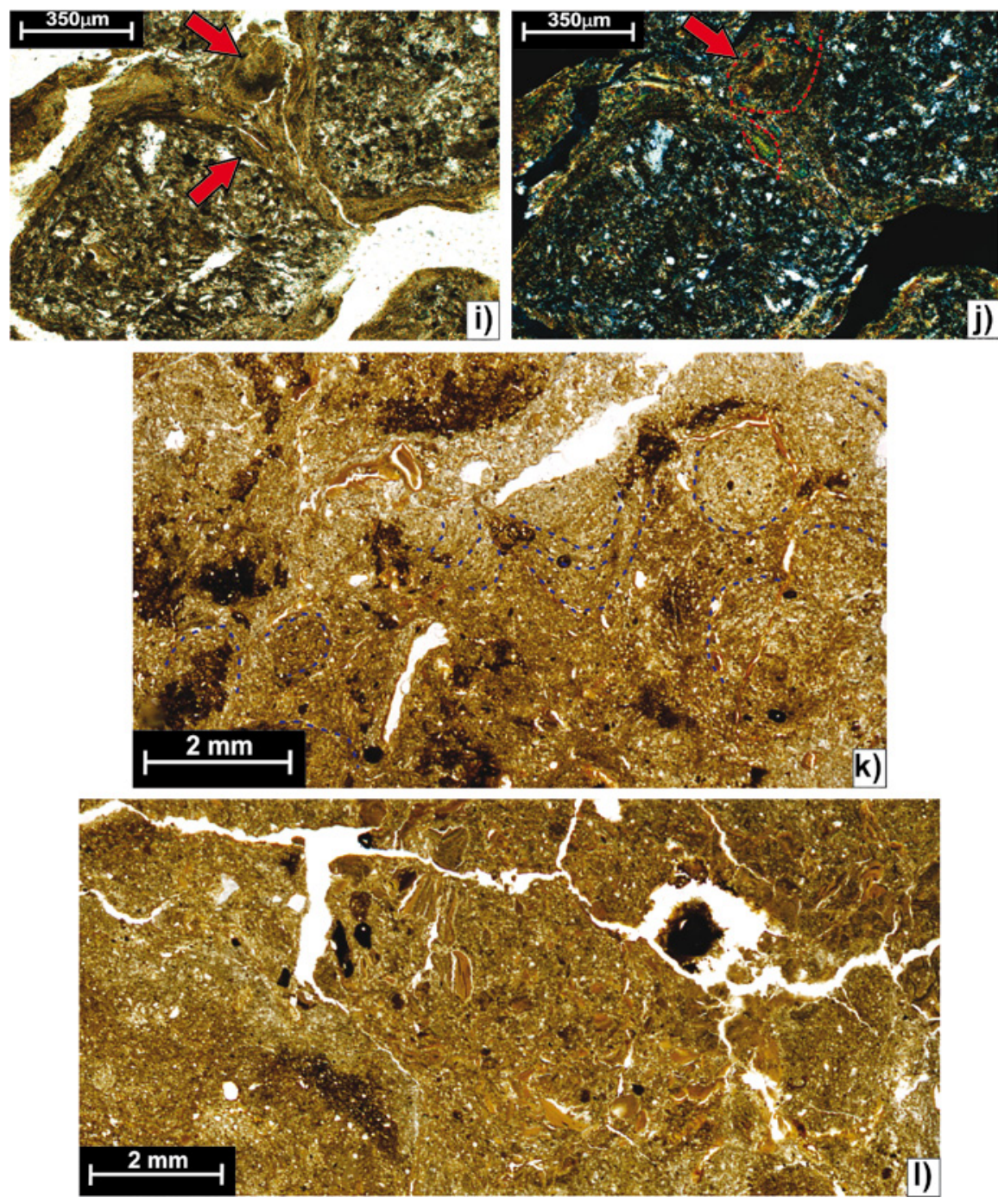

Fig. 2: Micromorphology of the study section: i. Deformed pedofetures. Deformed clay coatings showing a "twisted" morphology and displacing the groundmass (red arrow) around blocky microstructure in Btg2 horizon of OL3, photomicrograph (PPL).

j. same as $2 j$, (XPL). The red discontinuous lines show the "twisted" morphology with the displacing of the groundmass. Note the high interference color inside and outside of the blocky microstructure, related to a primary phase of clay illuviation (2:1 clay structure). k. Orbiculic fabric (blue discontinuous line) in Bg2 horizon in OL4. High resolution image (4600 dpi) of scanned thin section.

l. Fragmented clay cutans possibly associated to bioturbation in Bg2 horizon of OB4. High resolution image (4600 dpi) of scanned thin section.

Abb. 2: Mikromorphologie des untersuchten Abschnitts:

i. Wie h., gekreuzte Polarisatoren. Man beachte die hohen Interferenzfarben aufgrund der 2:1-Struktur der Tonminerale.

j. Fragmente illuvialer Tonüberzüge verdrängen die Matrix im Btg2-Horizont von OL3. Mikroskopaufnahme, (PPL).

k. Wie 2j., gekreuzte Polarisatoren. Auch hier ist die hohe Interferenzfarbe innerhalb des primär illuvial verlagerten Fragments zu beachten. Der rote Pfeil kennzeichnet teilweise in der Matrix assimilierte Toncutane.

l. In der Bildmitte Fragmentierung von Toncutanen in Bg2 (OB4), möglicherweise durch Bioturbation. Hochauflösende Darstellung (4600 dpi) von gescanntem Dünnschliff.

yellowish brown with mottles varying from gray to brownish gray and red. The structure is subangular blocky and platy. Vertical cracks filled by grayish material cross the horizon. Fe/Mn-concretions are frequent (0.1 to 0.5 in diameter).

OL4. Third paleosol complex (depth 900-1200 cm). This unit is constituted by $\mathrm{Bg} 1-\mathrm{Bg} 2-\mathrm{BCg} 1-\mathrm{BCg} 2-\mathrm{BC} \operatorname{tg} 1-\mathrm{BCtg} 2-$ $\mathrm{G}$ horizons (Figure 1), which are very compact and have silty loam textures. The unit is crossed by vertical fissures filled by dark gray, stagnic materials. In the central part of the fissures we observe clay and silt coatings (the latest distinguish by their coarser texture). The Bg1horizon is strongly patchy and wavy $(900-950 \mathrm{~cm})$. Dark brown material alternates with light grey vertically oriented mottles. The exterior part of the mottles is surrounded by yellowbrown oxidized zones. Structure is platy and angular blocky. Abundant $\mathrm{Fe} / \mathrm{Mn}$ - concretions $(0.5-1 \mathrm{~cm}$ in diameter) are found. Dark coatings are present, especially on the surface of platy blocks. Bg2 $(950-990 \mathrm{~cm})$ clearly differs from the previous horizon by the increase of gray areas (stagnic) on the ped surfaces. Fe/Mn-concretions are also present but in lesser amounts. BCg1 $(990-1030 \mathrm{~cm})$ is patchy, paler than the previous Btg, but with a similar structure. In this horizon the vertical fissures are thicker than in the upper part. Fe and Mn coatings are frequent. BCg2 $(1030-1100 \mathrm{~cm})$ is very similar to $\mathrm{BCg} 1$ but less patchy. BCtg1 (1100-1140 $\mathrm{cm})$ and BCtg2 $(1140-1180 \mathrm{~cm})$ are alike, but BCtg1 is more clayey and shows dark clay coatings. Round vertical channels are common. $\mathrm{G}(1180-1200 \mathrm{~cm})$ is more homogeneous in color with a grey matrix, showing small brown rusty mottles. Structure is well developed and consists of small subangular blocks. It is clear that vertical channels do not enter into this horizon.

OL5. Fourth paleosol sequence (1200-1520). This lowermost stratigraphic level is clearly a pedocomplex, composed by Bg-G-2Bg-2BCg-3Ah-3EBg-3Bg-3Cg horizons (Figure 1). The upper Bg $(1200-1250 \mathrm{~cm})$ is pale brownish yellow with rusty and grey mottles. It is constituted by very fragile subangular blocks with a silty clay texture. Its transition to the G horizon is wavy and gradual. The $G$ horizon $(1250-1290 \mathrm{~cm})$ is bluish gray with black and rusty mottles. Due to the occurrence of small subangular blocks the structure is better developed than in the $\mathrm{Bg}$ horizon. Mn segregations are common. The boundary with the next 2Bg horizon $(1290-1370 \mathrm{~cm})$ is clear and wavy. It is pale brown with brown, rusty and black mottles. It has a silty loam texture. Friable subangular blocky structure is dominant with a tendency to break into crumby, granules. $\mathrm{Mn}$ is segregated in pores and channels. Very few clay coatings are present in channels and on ped surfaces. The boundary with the less structured $2 \mathrm{BCg}(1370-1415 \mathrm{~cm})$ is wavy and gradual. Rounded rock fragments are present in this 
horizon marking a clear and straight limit to the next $3 \mathrm{Ah}$ horizon (1415-1430 cm), which has a very dark gray color with rusty and brown mottles. It is a silty clay loam with a very fragile subangular blocky-granular structure. Charcoal fragments and few clay coatings are found in channels and pores. The transition to the $3 \mathrm{EBg}$ horizon is clear and slightly wavy. $3 \mathrm{EBg}(1430-1450 \mathrm{~cm})$ is pale gray. Rusty, brown, and black mottles are present. Its structure is constituted by fragile, small subangular blocks and gravels are frequent. $3 \mathrm{Bg} 1(1450-1490 \mathrm{~cm})$ is yellowish brown with grayish mottles. It is a silty clay with a fragile structure composed of subangular blocks. Mn segregations and ferruginous hypocoatings are abundant in pores and channels. The lower part of this horizon is more grayish. Its contact with the underlying $3 \mathrm{Cg}(1490-1520 \mathrm{~cm})$ is abrupt. It is build up by gravels with abundant Mn segregations and dark-brown mottles around the gravels, which increase in size with depth.

\subsection{Micromorphology}

The main micromorphological features observed in the Oberlaab section can be divided into four kinds: biogenic components and features, redoximorphic pedofeatures, clay coatings, and deformed pedofeatures. In most cases the proportions are obtained by using the scanned thin sections and the Image Pro software.
Biogenic components and features. These materials include root traces, humus, coprolites, channels, and charcoal. They are clearly recognizable in both the modern soil and the OL4 profiles. The Ah and AE horizons of the modern soil (OL1) are characterized by strong bioturbation including the presence of chambers with loose and discontinuous coalescent excremental infillings (Figure 2a) associated with root traces (in some cases more or less degraded). Dark humus impregnates the matrix, in cases where a granular structure dominates. Biogenic materials in OL4 are less diverse. They are presented only by charcoal fragments with a well preserved cellular structure, as well as passage features of mesofauna.

Redoximorphic pedofeatures. These kinds of pedofeatures include ferruginous concretions, hypocoatings, and bleached areas. Paleosols contain the highest concentrations in comparison to the modern soil (Figure 3). However, Fe concretions are frequent in the $\mathrm{G}$ horizons of the modern soil, where they show sharp boundaries to the matrix (Figure $2 \mathrm{~b})$. Fe concretions and hypocoatings reach the maximum (19\%) in the $\mathrm{BCg} 1$ horizon of OL4. The highest proportion of bleached areas (65\%), which permit the estimation of zones where iron has been removed, was found in the $\mathrm{Bg} 2$ horizon of OL4 (Figures 2c and 2d, Figure 3). It is interesting that the contact between bleached zones and groundmass is diffuse in surficial horizons, however, in the lower part of the profiles, boundaries are more abrupt. Figures $2 \mathrm{e}$ and $2 \mathrm{f}$ clearly

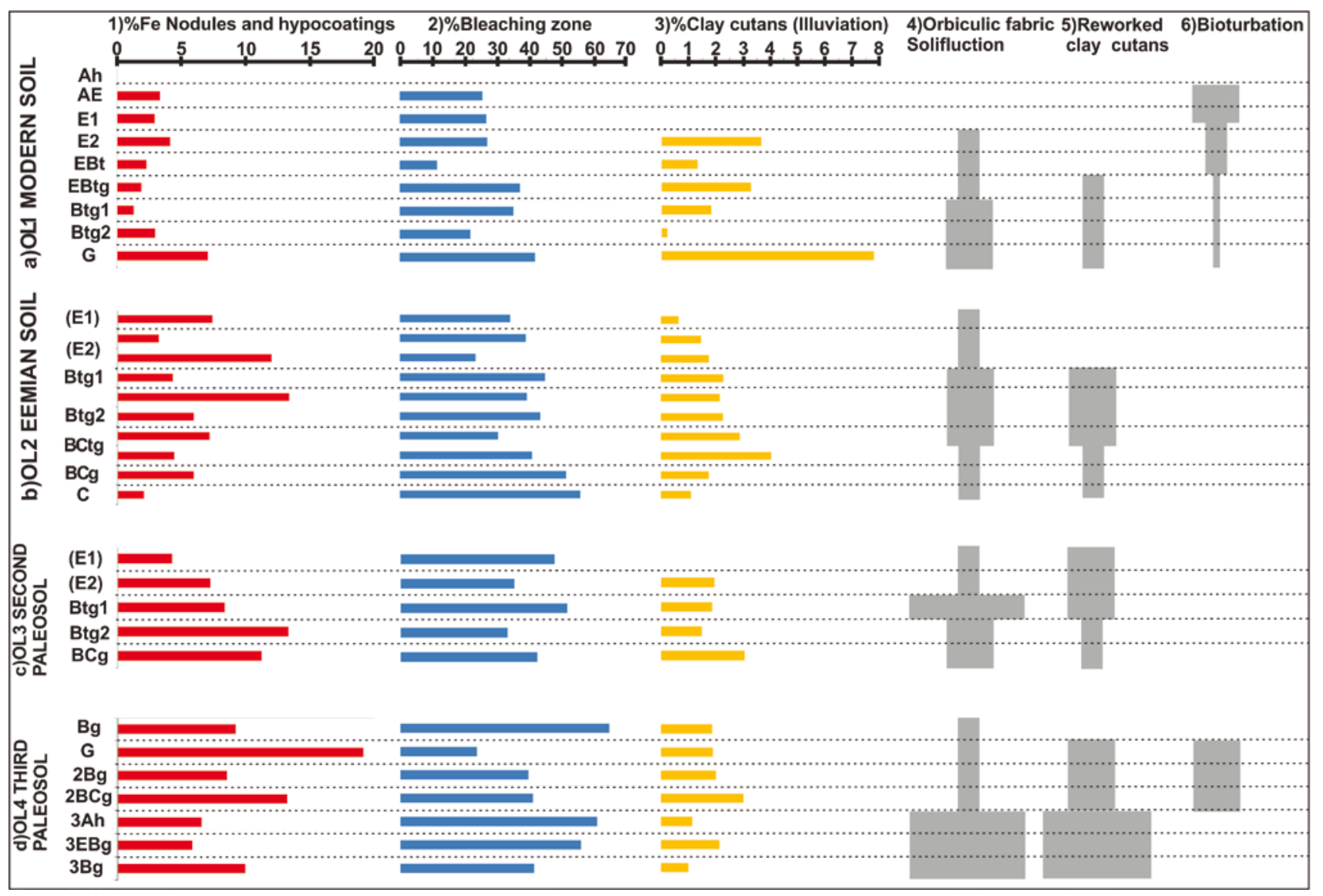

Fig. 3: Proportion of micropedofeatures in the Oberlaab sequence, according to the image analysis using the software Image Pro in high resolution image (4600 dpi) of scanned thin section.

Abb. 3: Quantifizierung von Mikrobodenmerkmalen, basierend auf der Bildanalyse mit der Software Image Pro, in hochauflösender Darstellung (4600 dpi) von gescanntem Dünnschliff. 
show this kind of contact in the BCg horizon of OL3.

Clay coatings. Clay coatings are common in the modern soil; coating content varies from 1 to $3.5 \%$. Surprisingly, the G horizon reaches a $7 \%$ the maximum in the whole sequence (Figure 3). In the Eemian paleosol (OL2), particularly in the $\mathrm{Btg}$ and $\mathrm{BC}$ tg horizons, the amounts are also high (2.1 to $4 \%$ ). The lowest concentration of clay coatings is present in the OL3 and OL4 profiles (Figure 3). The "impurity" of the clay coatings varies in the profiles. In the modern soil most of the coatings are pure and limpid (with yellowish colors), meanwhile in the paleosols coatings show Fe microlaminations and pigmentations (Figure $2 \mathrm{~g}$ and $2 \mathrm{~h}$ ).

Deformed pedofeatures. All studied paleosols, as well as the modern soil show deformation of some pedofeatures. This deformation is more evident in Btg horizons, where the clay coatings are assimilated inside the bleached, silty groundmass and exhibit a "twisted" morphology (Figure $2 \mathrm{i}$ and 2j). The presence of fragmented and displaced groundmass blocks with "cloud" structures as well as orbiculic fabrics are also common (Figure 2k). Additionally, in OL3 and OL4 small blocks are fragmented and displaced. In such blocks we observe two different generations of clay coatings: the first one (thin and discontinuous clay coatings) is inside the blocks; the second one (with thicker coatings) covers the aggregates. Another kind of "deformed" coatings is present in BCg horizons (particularly in BCg horizon of OL4). These coatings are fragmented and rounded, indicating reworking processes (Figure 2l).

Besides the micromorphological descriptions made for the thin sections we analyzed the bulk mineral com-

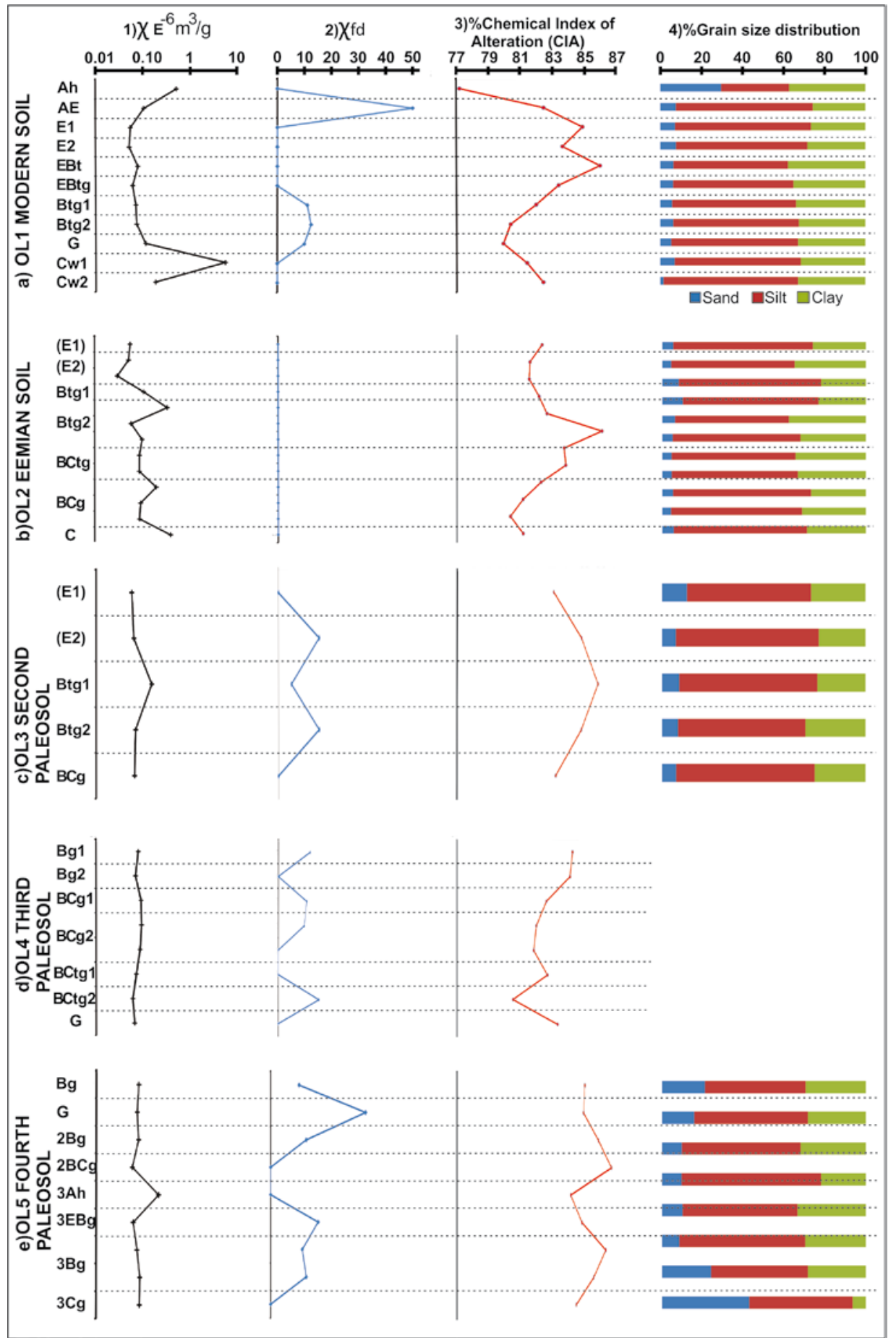

Fig. 4: Selected analytical properties of the study sequence: Magnetic susceptibility $(\chi E-6 \mathrm{~m} 3 / \mathrm{g})$; frequency dependence of susceptibility $(\chi f d \%)$ : grain size distribution (\%).

Abb. 4: Ausgewählte Analyseergebnisse des untersuchten Abschnitts. 
position of sand and silt fractions. The mineral content is mostly constituted by quartz, potassium feldspar, and mica (muscovite), which are moderately to well sorted. Biotite is present in low quantities and mostly concentrated in the sand fraction. Heavy minerals such as amphiboles (in some cases with "serrated" morphology), epidote, and garnet are concentrated in the silt fraction and demonstrate angular shape. Some schist fragments are recognizable in primary sedimentary layers. This mineralogical assemblage coincides well with the reports from other loess-paleosols sequences of Upper Austria (Terhorst et al. 2011).

\subsection{Analytical properties}

The silt fraction in the modern soil ranges from 33 to $67 \%$. The surficial Ah horizon shows a high amount of sand $(30 \%)$, contrasting to that obtained in the rest of the profile (Figure 4). The clay fraction exhibits similar proportions in all horizons, however, it increases in EBt and Btg horizons. The $\mathrm{Cw}$ horizon contains the highest proportion of silt $(64-66 \%)$. Magnetic susceptibility $(\chi)$ is generally low in all horizons, but with high values in $\mathrm{Cw} 1$ and Ah horizons. The low values of the frequency dependence of susceptibility $\chi \mathrm{fd} \%$ indicate a null contribution of super paramagnetic (SP), ultrafine grains $(<0.05 \mu \mathrm{m})$. To the contrary, SP particles dominate in AE horizon (Figure 4). CIA values (chemical index of alteration) are high, increasing from $77 \%$ in $\mathrm{Ah}$ to $85 \%$ in EBt (Figure 4). The lowermost part of the profiles records slightly lower percentages.

In the Eemian soil (OL2) the silt fraction is dominant (55$70 \%$ ). The whole profile shows a low proportion of sand. Clay content reaches a maximum in Btg2 horizon, although (E1) and (E2) horizons on the top show a high proportion as well (Figure 4). The values of magnetic susceptibility $(\chi)$ are very low in (E1) and (E2) but increase in Btg. $\chi \mathrm{fd} \%$ values are very low in the whole profile, revealing that none of the horizons has SP contribution (Figure 4). CIA pattern shows a maximum in the $\mathrm{Btg} 2$ horizon (87\%) and reach the lowest value in $\mathrm{BCg}(80.3 \%)$.

OL3 has a higher percentage of sand (7 to $12 \%$ ) than the Eemian soil, however, silt still dominates (61 to 70\%). In this unit the clay amount is lower (25-29\%) and there is no significant difference among the horizons, although a slightly higher content is obvious in Btg2 (Figure 4). In case of magnetic parameters, $\chi$ has similar values, while $\chi \mathrm{fd} \%$ shows strong differences varying from zero in the (E1) to $14 \%$ in (E2), $5 \%$ in Btg1, $14 \%$ in Btg2, and zero in BCg. This contrast evidences the presence of discontinuities (Figure 4). CIA values are also very similar (83-85\%). The highest weathering degree corresponds to Btg1 (Figure 4).

OL4 profile shows very low and homogeneous $\chi$ values, but high percentages of $\chi \mathrm{fd} \%$ indicate an elevated contribution in SP particles. However, this behavior is not continuous, because in $\mathrm{Bg} 2$, in the lowermost part of $\mathrm{BCg} 2$ (in $180-200 \mathrm{~cm} \mathrm{depth})$, and in the G horizon, $\chi \mathrm{fd} \%$ drops to zero (Figure 4). CIA varies from $84 \%$ in Bg horizon decreasing to $82 \%$ in BCtg2.

OL5 has high variability in the proportions of the different size fractions, which reveal the influence of alluvial sedimentation. Sand varies from $8 \%$ in the Bg horizon to $42 \%$ in the lowermost part of the profile, where gravel appears. OL5 has very low values in $\chi$, although an enhancement without contribution of SP grains is noted in the 3Ah horizon, which is detectable in the uppermost part of the profile in the $\mathrm{Bg}$ and $G$ horizon (Figure 4). CIA is equally variable. The upper $\mathrm{Bg}$ as well as $\mathrm{G}$ horizon are slightly less weathered than $2 \mathrm{Bg}$ and $2 \mathrm{BCg}$ and $3 \mathrm{Ah}$ and $3 \mathrm{Cg}$ show the lowest CIA percentages.

\section{Discussion \\ 4.1 Chronostratigraphy and correlation of the Oberlaab profile}

Although no instrumental absolute dates are available in Oberlaab it is possible to establish a local chronostratigraphic scheme taking into account the stratigraphic classification of SCHOLGER \& TERHORST (2011) and TERHORST et al. (2011) developed for the Middle Pleistocene profiles in the Northwest of Austria.

Terhorst (2007) points out that the Oberlaab sequence contains four interglacial paleosols (1st, 2nd, 3rd, 4th) thus covering at least the last five glacial periods (thus the development of the Mindel terrace (Younger Deckenschotter) occurs at least during MIS 12). According to the stratigraphic schemes, Oberlaab records completely the main paleoclimatic stages from MIS 12 to MIS 5e, parts of the last glacial, as well as the Holocene soil. This interpretation is in good agreement with the pedostratigraphical schemes of the cover layers in Wels-Aschet, Neuhofen, and Oberlaab and our studies can clearly be positioned in the regional stratigraphic context of the area. This contradicts to the view of Preusser \& Fiebig (2009), who propose younger ages for the Wels-Aschet sequence including the Older Deckenschotter of the Günz glaciation, based on luminescence dating. For instance, they suggest an age of $252 \pm 29 \mathrm{ky}$ for the 4th interglacial paleosol (MIS7). Paleomagnetic studies done in the same sequence also contradict the chronostratigraphy of Preusser \& Fiebig (2009) documenting the presence of the Calabrian Ridge excursions: CR1 (325-315 ka) and CR2 (525-515 ka) inside the 3rd and in the base of the 4th interglacial pedocomplex, respectively (SCHOLGER \& Terhorst 2011). Consequently, OL5 can be attributed to MIS 11 with three phases of soil formation: Bg-G-2Bg$2 \mathrm{BCg}-3 \mathrm{Ah}-3 \mathrm{EBg}-3 \mathrm{Bg}-3 \mathrm{Cg}$. The upper $\mathrm{Bg}$ horizon correlates with the 4th interglacial paleosol, described by TERHORST (2007) and Terhorst et al. (2011) in Oberlaab, Neuhofen, and Wels-Aschet, but in our case clay coatings are not observed in this unit as in other sequences. TERHORST (2007) mentions an underlying $G$ horizon in Neuhofen and WelsAschet, but without the $2 \mathrm{Bg}-2 \mathrm{BCg}$ horizons, which are present in our section. Furthermore, the lower paleosol has not been described before in the area. There are clear differences in analytical properties, which reflect soil formation cycles: CIA values are low in the $\mathrm{Bg}-\mathrm{G}, 3 \mathrm{Ah}, 3 \mathrm{EBg}$, and high in $2 \mathrm{Bg}-2 \mathrm{BCg}, 3 \mathrm{Bg}$ horizons (Figure 4 ).

The subsiding stratigraphic levels of OL4 and OL3 correlate with the 3 th and 2 th interglacial paleosols described for Upper Austria (Terhorst 2007; 2013, this volume; TerHORST et al. 2011). OL4 is developed on sediments which are classified as MIS 10 deposits and represent an intensive glacial phase. Therefore paleosol formation could correspond best to the MIS 9 (c.f. LISIECKI $\mho$ RAYMO 2005). On 
the base of the pedostraphic observations, the next sedimentation events can be correlated to the MIS 8 period, which records a weaker glacial phase (c.f. LisIEcki \& RAYMo 2005). Pedogenesis of the OL3 unit can be related to the interglacial period of MIS 7.

Both profiles OL3 and OL4 are pedocomplexes (TERHORST 2007; Terhorst et al. 2012). According to our field observations significant differences and discontinuities are not detectable between both units. However, some quantitative analytical characteristics clearly indicate them. In OL4 we can separate three phases of pedogenesis: the first phase corresponds to the development of the lowermost $G$ horizon, reflected by different properties: CIA values are higher than in the overlying BCtg $2, \chi \mathrm{fd} \%$ is zero with no contribution of SP magnetic particles. The second phase comprises the horizons $\mathrm{BCgt} 1$ and $\mathrm{BCg} 2$, which tend to have similar characteristics although CIA values are higher in BCtg1, a fact which is related to a higher amount of clay. The third phase corresponds to the formation of the upper horizons $\mathrm{Bg} 1-\mathrm{Bg} 2-\mathrm{BCg} 1-\mathrm{BCg} 2$. These results are not in good agreement with those obtained by TERHORST (2007), who reports the presence of a pedocomplex in Oberlaab with only 2 paleosols, one described as a Bw horizon with stagnic properties superimposed by a Btg horizon. In WelsAschet, Terhorst et al. (2012) find the 3th paleosol, containing two Bt horizons with moderate weathering degree. Coincidences are in terms of the gleying process, because in Oberlaab as in other sections in Lower Austria, elevated amounts of $\mathrm{Mn}$ have been found in different forms.

On the other hand, OL3 is another pedocomplex. Repeatedly, the profile has been characterized as monogenetic during field survey, however, analytical results could highlight specific differences, although the clay content is similar (Figure 4). CIA index and $\chi$ reveal maxima in the Btg1 horizon, which can be related to the high amount of clay (around 30\%). $\chi \mathrm{fd} \%$ values record significant differences in the contribution of magnetic particles, and thus can be explained by the presence of discontinuities (Figure 4). We have even found charcoal in Btg1 - probably because this horizon was close to the surface. Our results exhibit a discrepancy to those obtained by TERHORST et al. (2012) for the Wels-Aschet sequence, because on the basis of mineralogical analyses the authors conclude that the 2 th paleosol is less weathered than the 3 th one. Similar mineralogical results were obtained for earlier studied Oberlaab profiles (Terhorst et al. 2003). However, the presented CIA values, clay contents (40-32\%), as well as thick clay coatings observed in our study indicate a more advance weathering in the OL3 unit in comparison to OL4, and that means 2nd paleosol is more weathered than the 3rd one).

The multiphase pedogenesis detected in both units, OL3 and OL4, could be linked to the climatic fluctuations within MIS 7 and MIS 9. These stages demonstrate a complex pattern in the $\delta 18 \mathrm{O}$-record with warm intervals alternating with cold episodes. Earlier BRONGER et al. (1998) supposed that pedocomplexes PKII and PKIII in loess-paleosol sequences of Tadjikistan reflect climatic fluctuations within MIS 7 and MIS 9, respectively. More detailed correlation of pedocomplexes and marine isotope curve is limited by the lack of a reliable age control.

The OL2 profile, regarded as the Eemian soil (1st inter-

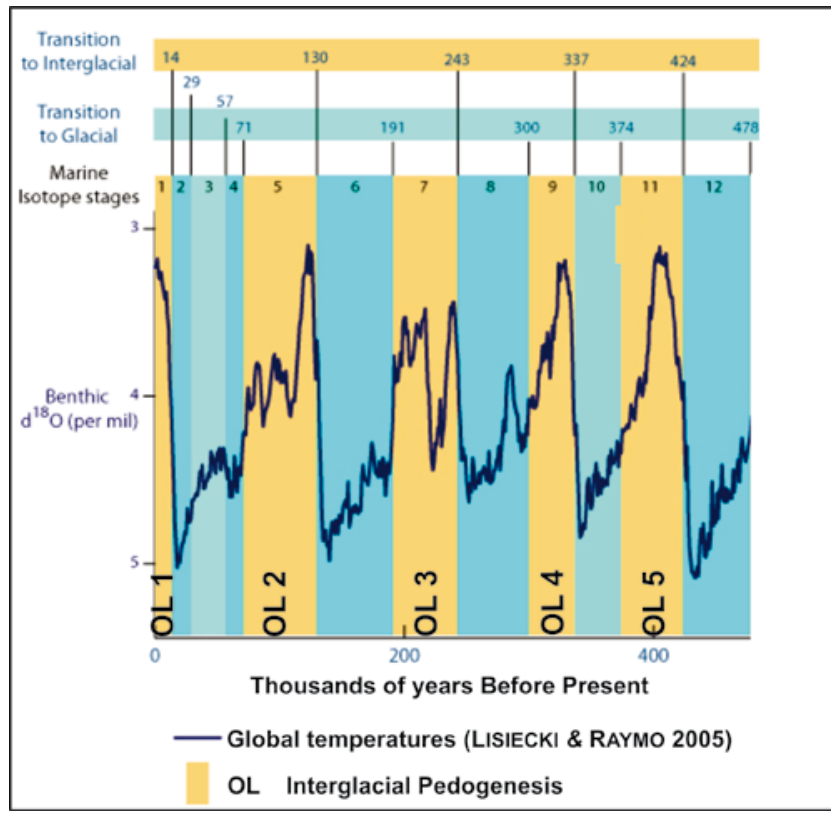

Fig. 5: Correlation of paleosols in Oberlaab with the Marine Isotope Curve. Abb. 5: Korrelation von Paläoböden in Oberlaab mit der marinen Isotopenkurve.

glacial paleosol), occupies the next stratigraphic level. Its age has been well established by several instrumental dates: OSL and paleomagnetism in other sections, in particular in the Wels-Aschet sequence (Preusser \& Fiebig 2009; Scholger \& Terhorst 2011), but in the case of Oberlaab such results are not available. In Wels-Aschet, the Eemian soil is developed on loessic sediments of the Riss glaciation, which is $142 \pm 18 \mathrm{ky}$ (MIS 6) according to PreUsSER \& FIEBIG (2009). On top of the MIS 5e-Eemian soil the Blake event ( 117 ka) is proved by Scholger \& Terhorst (2011; 2013, this volume) in Wels-Aschet. The Eemian soil in unit OL2 is correlated to MIS 5e in this study, based on the results of further sequences in Austria. In general, the paleosol displays fewer stagnic properties and less compaction than the older paleosols. Furthermore, its stratigraphic position is situated below the Würmian sediments. From the analytical point of view the interglacial pedogenesis is proved by intensive clay illuviation, coinciding with higher CIA values.

OL1, which correspond to the Holocene soil, is separated from the Eemian paleosol by loess-like deposits characteristic for the Würmian glaciation. There is no evidence for well-developed soils in these deposits, only reworked layers are present.

According to the proposed pedostratigraphy, Figure 5 shows the correlation of the study section with the Marine Isotope Curve (acc. to Lisiecki \& RAYMo 2005).

\subsection{Pedogenic trends in Oberlaab induced by climate change or/and geomorphic processes}

The loess-paleosol sequence in Oberlaab contains several units, which developed different specific properties. Although some of the specific patterns are found in the whole section, their intensity is strongly related to pedogenic and geomorphic processes. All units are characterized as pedo- 
complexes, and can be welded, thus difficulties in the recognizance of every single soil cycle can emerge.

In the sequence we studied it is clear that the lower units, especially OL4 and OL5, developed under conditions produced by water saturation, which gave rise to redoximorphic processes. The lowest OL5 unit shows the formation of a diagnostic $G$ horizon with a pale reduced soil matrix and relatively few iron segregations. These properties correspond to gleyzation in a permanently reduced soil environment, which lets us suppose a shallow groundwater table. OL4 demonstrates patchy $\mathrm{Bg}$ horizons, Fe-Mn concretions and hypocoatings with bleached groundmasses. In fact, the highest concentrations of ferruginous pedofeatures as well as bleached zones are found in OL4 (Figure 3). These characteristics correspond to stagnic properties related to temporary saturation with surface water. Very limited development of clay illuviation agrees with the hypothesis of pedogenesis in a poorly drained soil environment.

The stagnic and gleyic features become less frequent in the upper paleosols. Here, clay illuviation is dominant, with thick and dark clay coatings. From micromorphological results the Eemian (OL2) and Holocene soils have the highest percentages of illuvial clay (2.1 to $4 \%$ ). On the other hand, coatings in OL3, OL4, and partly in OL2 (for details see SEDOV et al. 2013, this volume) are deformed and displaced, thus the material has been also affected by gleyzation and cryogenesis. In fact, only in the upper part of the modern soil clay coatings are pure with a yellow color. Its inferior part (G horizon) contains the highest amount of clay coatings, which are "dirty", laminated or having reddish colors, with pigmentations. This horizon has also a low magnetic susceptibility value and considerably lower weathering degree. TERHORST (2007) suggests it corresponds to a previous phase of soil formation that probably occurred $\neq$ during MIS2 to 3.

In summary, the main trend of change of pedogenic processes in the Oberlaab sequence is the following: gleyzation at the base (OL5-OL4), stagnic processes in the central part (OL4-OL3) and clay illuviation in the upper units (OL2-OL1).

Which soil forming factors control these pedogenic trends? It seems that climate is only one factor due to the fact that all units are formed under humid climates evidenced by the formation of stagnic and gleyic features, clay neoformation and illuviation, and silt and/or iron illuviation. Differences between the pedocomplexes are well expressed in the intensity of the involved processes. Additionally, changes in temperature may be somewhat responsible. Lower units could reflect the influence of cooler environments, while the upper ones are affected by warmer climates.

The geomorphic position of the studied paleosols also evidently affected pedogenesis. The lowermost paleosols are situated at a lower level in the geoform, and were more affected by waterlogged conditions (high groundwater table or flooding). This is evident in OL5, where fluvioglacial processes formed a gravelly alluvial deposit with a high content of Mn concretions.

The upper paleosols are located in better drained positions away from the influence of groundwater and inundations. This can be explained by the aggradation of the terrace and by lower levels of the younger terraces. In particular, the Eemian soil shows a well-developed formation stage charac- terized by a high weathering status. The well-drained geomorphological position favors clay illuviation.

Another important process observed in the lower paleosols is related to deformation of pedofeatures, which can be caused by bioturbation, as well as by cryogenesis and gelifluction. Orbiculic fabrics, silt concentrations, and platy structures are related to such kind of processes. According to our observations these features are more frequent in OL5 and OL4 (Figure 3) due to a higher intensity of glacial periods. However, lower sedimentation and/or more intensive erosion processes cannot be neglected. According to Lisiecki \& RAYMo (2005) during MIS 12 and 10 severe glacial phases occurred, after which OL5 and OL4 are formed (Figure 5). During MIS 8 the glacial phase is much weaker, thus characteristics found in OL3 are clearly less affected by cryogenesis.

\section{Conclusion}

The Oberlaab sequence on top of a Mindel terrace (Younger Deckenschotter) is constituted by four interglacial paleosols, which developed most probably during the Marine Isotope Stages MIS 11, MIS 9, MIS 7, and MIS 5, respectively. Similar to other interglacial paleosols of the same age in Upper Austria, the paleosols are formed as pedocomplexes in Oberlaab. Studied properties reveal the dominance of humid conditions in the whole section, but with differences in the intensity of pedogenic processes involved in the formation of each pedostratigraphic level. We assume that the oldest paleosol OL5 can be correlated to the 4th interglacial paleosols found in Neuhofen, Wels-Aschet, and in earlier studied profiles in Oberlaab. We correlate this soil to MIS 11. The pedocomplex is affected by strong gleyzation. OL4, which is the $3^{\text {rd }}$ interglacial paleosol, is characterized by the signs of strong reductomorphic features, partly deformed and with orbiculic fabrics, which are associated with later cryogenesis, probably during MIS 8. OL3 also has properties related to stagnic processes, but clay illuviation and a higher degree of weathering are evidence of its formation under warmer conditions during MIS 7. The Eemian soil (OL2) is the best developed and reflects warm interglacial conditions.

\section{Acknowledgments}

We thank to the financial support of the project "Polygenetic models for the Pleistocene paleosols: new approach to decoding the paleosol-sedimentary records" (International Council Science Union). We also aknowledge support from Conacyt-DLR as well as CONACYT grant for "Estancias Posdoctorales al Extranjero" to H. Cabadas. Many thanks to Lance Wallace for correcting the manuscript, and to Eligio Jiménez and Jaime Díaz for thin section preparation and the grain size separation, as well as Jorge Rivas for magnetic measurements. Rufino Lozano contributed with the X-Ray fluorescence analyses.

\section{References}

Bettis, E.A. III, Muhs, D.R., Roberts, H.M. \& Wintle, A.G. (2003): Last glacial loess in the conterminous U.S.A. - Quaternary Science Reviews, 22: 1907-1946. 
Bronger, A., Winter, R. \& Heinkele, T. (1998): Pleistocene climatic history of East and Central Asia based on paleopedological indicators of loess-paleosol sequences. - Catena, 34: 1-17.

Buggle, B., Glaser, B., Hambach, U., Gerasimenko N. \& Markovic, S. (2011): An evaluation of geochemical weathering indices in loesspaleosol studies. - Quaternary International, 240: 12-21.

Bullock, P., Fedoroff, N., Jongerius, A., Stoops, G., Tursina, T. ひ BABEL, U. (1985): Handbook for soil thin section description. - 152 p.; Wolverhampton, U.K. (Waine Research Publications).

CAstro, D.A. (1989): Petrografía básica: Texturas, clasificación y nomenclatura de rocas. - 143 p.; Madrid (Paraninfo).

DeAring, J.A. (1994): Environmental Magnetic Susceptibility: Using the Bartington MS2 System. - 111 p. (Chi Publishing) Lincoln, United Kingdom.

Dearing, J.A., Bird, P.M., Dann, R.J.L. \& Benjamin, S.F. (1997): Secondary ferrimagnetic minerals in Welsh soils: a comparison of mineral magnetic detection methods and implications for mineral formation. - Geophysical Journal International, 130: 727-736.

Feng, Z.D., TANG, L.Y., MA, Y.Z., Zhai, Z.X., Wu, H.N., Li, F., Zou, S.B., YAng, Q.L., Wang, W.G., Derbyshire, E. \& LiU, K.B. (2007): Vegetation variations and associated environmental changes during marine isotope stage 3 in the western part of the Chinese Loess Plateau. Palaeogeography, Palaeoclimatology, Palaeoecology, 246: 278-291.

FINK, J. (1976): Exkursion durch den österreichischen Teil des nördlichen Alpenvorlandes und den Donauraum zwischen Krems und der Wiener Pforte. - Mitteilungen der Kommission für Quartärforschung der Österreichischen Akademie der Wissenschaften 1: 113 pp.

Haesaerts, P., Damblon, F., Bachner, M. \& TrnkA, G. (1996): Revised stratigraphy and chronology of the Willendorf II sequence, Lower Austria. - Archaeologia Austriaca, 80: 25-42.

IUSS Working Group WRB (2007): World Reference Base for Soil Resources 2006, first update 2007. World Soil Resources Reports No.103. FAO Rome.

KoHL, H. (1976): Lehmgrube der Ziegelei Würzburger in Aschet bei Wels.Mitteilungen der Kommission für Quartärforschung der Österreichischen Akademie der Wissenschaften, 1: 37-41.

Kukla, G.J. (1978): The classical European glacial stages: correlation with deep-sea sediments. - Transactions of the Nebraska Academy of Science, 6: 57-93.

LiU, T. (1985): Loess in China (2nd ed.). - 224 pp.; Beijing (China Ocean Press) and Berlin, (Springer-Verlag).

Liu, T.S., Guo, Z.T., Liu, J.Q., Han, J.M., Ding, Z.L., Gu, Z.Y. \& Wu, N.Q. (1995): Variations of eastern Asian monsoon over the last 140,000 years. - Bulletin de la Société Géologique de France, 166: 221-229.

Lisiecki, L.E. ¿ RAymo, M.E. (2005): A Pliocene-Pleistocene stack of 57 globally distributed benthic d18o records. - Palaeoceanography, 20: $1-17$.

Muhs, D.R., \& Bettis, E.A. III. (2000): Geochemical variations in Peoria Loess of western Iowa indicate paleowinds of midcontinental North America during last glaciations. - Quaternary Research, 53: 49-61.

MuHs, D.R. ¿ ZÁRATE, M. (2001): Eolian records of the Americas and their paleoclimatic significance. - In: MARKGRAF, V. (ed.): Interhemispheric Climate Linkages. pp. 183-216; San Diego (Academic Press).

Muns, D.R. \& BetTis, E.A. III (2003): Quaternary loess-paleosol sequences as examples of climate-driven sedimentary extremes. - In: CHAN, M.A. \& Archer, A.E. (eds.): Extreme depositional environments: Mega end members in geologic time. Geological Society of America Special Paper, 370: 53-74.

Nesbitt, H.W. \& Young, G.M. (1982): Early Proterozoic climates and plate motions inferred from major element chemistry of lutites. - Nature, 299: 715-717.

Neugebauer-Maresch, C. (1996): Zur Stratigraphie und Datierung der Aurignacienstation am Galgenberg. - In: SvoвodA J. (ed.): Paleolithic in the Middle Danube Region. Archeologicky ustav, pp. 67, Brno.

Niederhuber, M. (1997): Stratzing/Krems-Rehberg. - In: Döppes, D. \&
RABEder, G. (eds.): Pliozäne und pleistozäne Faunen Österreichs. Österreichische Akademie der Wissenschaften, pp. 56-61,Wien.

Österreichische Stratigraphische Kommission (2004): Stratigraphische Tabelle von Österreich, Wien.

Quattrocchio, M.E., Borromei, A.M., Deschamps, C.M., Grill, S.C. \& ZavALA, C.A. (2008): Landscape evolution and climate changes in the Late Pleistocene-Holocene, southern Pampa (Argentina): evidence from palynology, mammals and sedimentology. - Quaternary International, 181: 123-138.

PÉcsi, M. (1990): Loess is not just the accumulation of dust. - Quaternary International, 7-8: 1-21.

PÉcsi, M. \& Schweitzer, F. (1993): Long-term terrestrial records of the Middle Danubian Basin. - Quaternary International, 17: 5-14.

Penck, A. \& Brückner, E. (1909): Die Alpen im Eiszeitalter, Vol. 1, pp. 393, Tauchnitz, Leipzig.

Preusser, F. \& Fiebig, M. (2009): European Middle Pleistocene loess chronostratigraphy: Some considerations based on evidence from the Wels site, Austria. - Quaternary International, 198: 37-45.

RozYCKI, S.Z. (1991): Loess and loess-like deposits. - 187 p. Warsaw (Ossolineum Press, Polish Academy of Sciences).

Scholger, R. \& Terhorst, B. (2011): Paläomagnetische Untersuchungen der pleistozänen Löss-Paläobodensequenz im Profil Wels-Aschet. Mitteilungen der Kommission für Quartärforschung der Österreichischen Akademie der Wissenschaften 19, 47-61.

Scholger, R. \& Terhorst, B. (2013): Magnetic excursions recorded in the Middle to Upper Pleistocene loess/palaeosol sequence Wels-Aschet (Austria). - E \& G Quaternary Science Journal, 62/1: 4-13, DOI 10.3285/eg.62.1.02, this volume.

Sedov, S., Sycheva, S., Targulian, V., Pi, T. ש Diaz, J. (2013): Last Interglacial paleosols with Argic horizons in Upper Austria and Central Russia: pedogenetic and paleoenvironmental inferences from comparison with the Holocene analogues. - E \& G Quaternary Science Journal, 62/1: 44-58, this volume.

Sun, X., Song, C., WANG, F. \& Sund, M. (1997): Vegetation history of the Loess Plateau of China during the last 100,000 years based on pollen data. - Quaternary International, 37: 25-36.

TARgulian, V.O. \& GorYACHKIN, S.V. (2004): Soil memory: types of record, carriers, hierarchy and Diversity. - Revista Mexicana de Ciencias Geologicas, 21: 1-8.

Terhorst, B. (2007): Korrelation von mittelpleistozänen Löss-/Paläobodensequenzen in Oberösterreich mit einer marinen Sauerstoffisotopenkurve. - Quaternary Science Journal, 56: 26-39.

Terhorst, B. (2013): Middle Pleistocene loess/paleosol sequences in Austria. - E \& G Quaternary Science Journal, 62/1: 4-13, DOI 10.3285/ eg.62.1.01, this volume.

Terhorst, B., Ottner, F., Poetsch, T., Kellner, A. ひ RÄhle, W. (2003) Pleistozäne Deckschichten auf der Traun-Enns-Platte bei Linz (Oberösterreich). - In: TeRHORST, B., Exkursionsführer zur 22. Tagung des Arbeitskreises Paläoböden in Oberösterreich. Tübinger Geowissenschaftliche Arbeiten, Reihe D 9: 115-155.

Terhorst, B., Ottner, F. \& Holawe, F. (2011): Pedostratigraphische, sedimentologische, mineralogische und statistische Untersuchungen an den Deckschichten des Profils Wels/Aschet (Oberösterreich). - Mitteilungen der Kommission für Quartärforschung der Österreichischen Akademie der Wissenschaften, 19: 13-35.

Terhorst, B., OtTner, F. \& Wriessnig, K. (2012): Weathering intensity and pedostratigraphy of the Middle to Upper Pleistocene loess/palaeosol sequence of Wels-Aschet (Upper Austria). - Quaternary InterNATIONAL, 26: 142-154.

VAN HuSEN, D. (2000): Geological processes during the Quaternary. - Mitteilungen der Österreichischen Geologischen Gesellschaft, 92: 135156.

VAN Husen, D. \& ReItner, J.M. (2011): An outline of the Quaternary stratigraphy of Austria. - E \& G Quaternary Science Journal, 60, 2-3: 366-387. 